\title{
Zone electrophoresis of poliovirus partially inactivated by formaldehyde
}

\author{
By A. POLSON, J. W. F. HAMPTON and D. DEEKS \\ From the C.S.I.R. and U.C.T. Virus Research Unit, Medical School, Cape Town, \\ and the Poliomyelitis Research Foundation, S.A.I.M.R., Johannesburg
}

(Received 22 June 1960)

\section{INTRODUCTION}

The mobility of a protein molecule in an electric field is dependent upon the net charge on the surface of such a particle. If the negative charges could be eliminated through reactions with a chemical substance, the positive charges would predominate and the isoelectric point (i.e.p.) would be lowered. The net effect of this would be that the molecule would have a higher mobility at a $\mathrm{pH}$ above its i.e.p. after removal of the negative charges. Formaldehyde is known to bind itself on to the terminal amino groups of protein particles and, in several cases, it has been found that the i.e.p.'s of formaldehyde-treated protein molecules were indeed lower than those of untreated molecules (Circle \& Smith, 1941).

Extensive use is being made of formaldehyde as an inactivating agent for the production of 'killed' virus vaccines against poliomyelitis and influenza; and, because of the proteinaceous character of the poliovirus surface, it is to be expected that the reaction of formaldehyde with the virus would be similar to that between this agent and protein molecules. This probability was examined from the following viewpoints :

(a) Do poliovirus particles behave differently in the electric field before and after inactivation by formaldehyde?

(b) Is it possible to separate 'live' from incompletely 'killed' virus particles by zone electrophoresis in a sucrose concentration gradient?

\section{MATERIALS AND METHODS}

Monkey tissue culture fluid provided the starting material consisting of 51 . of the $\mathrm{MEF}_{1}$ strain of Type 2 poliovirus. It was withdrawn during the routine preparation of vaccine at the time of filtration and had been exposed to formalin for 2 days. The titre before formalinizing was $10^{-7} \mathrm{TCID}_{50} / 0.5 \mathrm{ml}$. and $10^{-0.5} \mathrm{TCID}_{50} /$ $0.5 \mathrm{ml}$. on the second day of treatment with 9.5 parts per $10^{5} \mathrm{ml}$. as HCHO. The virus suspension was dialysed against three changes of 201 . of $0.02 \mathrm{M}$ phosphate buffer of $\mathrm{pH} 7 \cdot 0$ at $5^{\circ} \mathrm{C}$. As a precautionary measure to avoid bacterial growth 5 c.c. chloroform were added and the suspension was stored at $5^{\circ} \mathrm{C}$. until pervaporation was started. The formaldehyde content was $7 \cdot 7$ p.p. $/ 10^{5}$ after $2 \mathrm{hr}$, 1.95 p.p. $/ 10^{5}$ after $24 \mathrm{hr}$. and $0.2 \mathrm{p} . \mathrm{p} . / 10^{5}$ after $72 \mathrm{hr}$. dialysis. No live virus was detected in a titration of the material at this stage. 


\section{Pervaporation and ultracentrifugation}

The material was concentrated by pervaporation for 2 days, interrupted with overnight dialysis against $\mathrm{M} / 30$ phosphate buffer of $\mathrm{pH} \mathbf{7 \cdot 0}$ saturated with chloroform. The volume after pervaporation was 100 c.c. This concentrate was clarified by centrifugation at 10,000 r.p.m. for $10 \mathrm{~min}$. in a Phywe ultracentrifuge and further concentrated by pervaporation to 5.5 c.c. The live virus activity at this stage was $10^{-4 \cdot 0} / 0.5 \mathrm{ml}$. This is greatly in excess of what could be expected from the degree of concentration of the virus suspension.* Final purification was done by four cycles of ultracentrifugation in the Spinco, 12,000 r.p.m. for $10 \mathrm{~min}$. to remove coarse material, 30,000 r.p.m. for $90 \mathrm{~min}$. to concentrate the virus into a pellet, 12,000 r.p.m. for $10 \mathrm{~min}$. to remove coagulated material from the resuspended pellet and finally, 30,000 r.p.m. for $90 \mathrm{~min}$. to concentrate the virus into a pellet. Purification by chloroform treatment, Polson \& Hampton (1957), was avoided because of the uncertainty of the effect of chloroform on the formalinized virus.

\section{Zone electrophoresis}

The final virus pellet was suspended in $2 \mathrm{ml} .35 \%$ cane sugar dissolved in borate buffer of $\mathrm{pH} 8 \cdot 6$, a trace of phenol red being added to act as a reference substance in the subsequent zone electrophoresis. Zone electrophoresis was performed on the material according to the method described by Svensson \& Valmet (1955) and modified by Polson \& Cramer (1958). Electrophoresis was conducted on the material in borate buffer at $\mathrm{pH} 8.6$ for $18 \mathrm{hr}$. and the gradient column was photographed to register the position of the phenol red band as well as those of zones of opalescence. In Pl. 1 a photograph of the column is given. In the bottom of the column can be seen the capillary through which the material was introduced. A narrow zone of opalescence is shown approximately $4.5 \mathrm{~cm}$. from the tip of the capillary. A broad and faint opalescent zone is noticeable just below the phenol red band which is at $15 \mathrm{~cm}$.

The column was fractionated into sixteen sections $1 \mathrm{~cm}$. thick by running out of the capillary. The different samples were titrated for viable virus in mixtures of monkey kidney cells. $0 \cdot 1 \mathrm{ml}$. of each tenfold dilution was inoculated into five tubes. The tubes were observed for 21 days, in which period the fluid was changed five times.

The antigenicities of the different samples were tested by the method recommended by Gard, Wesslen, Fragreus, Svedmyr \& Olin (1956). Each sample was injected subcutaneously into six guinea-pigs, the animals receiving two injections of 0.25 c.c. each, spaced 7 days apart. Blood was collected by heart puncture 14 days after the second injection. (Pre-injection sera of all the animals were collected and stored.)

Preliminary neutralization tests were done in mice using the adapted strain of $\mathrm{MEF}_{1}$ as test antigen ( $10^{3}$ M.L.D. $/ 0 \cdot 03$ c.c.) on pooled sera from the various groups

* The increase in live virus activity may be explained by the reactivation effect which follows complete removal of formaldehyde by dialysis (Haas, Thomssen, Dostal \& Ruschmann, 1959). 
of animals. It was thus established which groups of sera contained the highest protection capacities. (Ten mice were used per serum pool and virus mixture.) Individual sera from these groups showing peak titres of antibody were then tested by the tissue culture technique.

In order to express the results in a quantitative form it was assumed that the length of the incubation period was inversely related to the titre of the fraction of virus which failed to be neutralized by the individual sera. In the present experiment the test virus had a titre of $10^{3} \mathrm{TCID}_{50} / 0.5 \mathrm{ml}$.

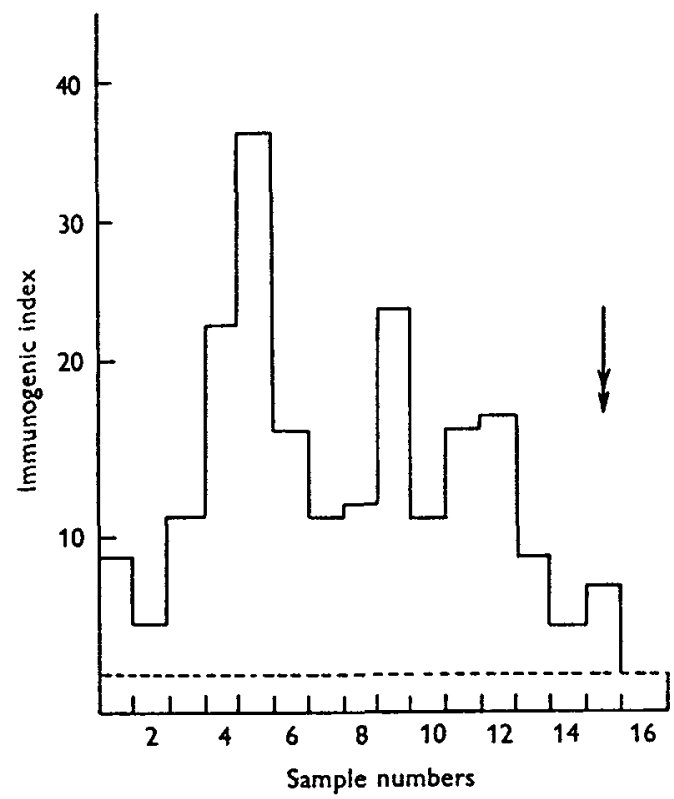

Fig. 1. Diagram showing the result of immunization of guinea-pigs with the different samples from the zone electrophoresis column. Pooled sera of each group of animals were tested against $10^{3}$ M.L.D./0.03 c.c. adapted $\mathrm{MEF}_{1}$ virus. The mixtures were injected intracerebrally into groups of ten mice. The ordinates measure the immunogenic index (response) of the different groups of guinea-pigs. The dotted line is the level in the diagram below which no antibody is present, and its position was obtained from control neutralization tests using pre-immunization guinea-pig sera.

The results of these neutralization tests in mice and tissue culture tubes are shown in Figs. 1 and 2 respectively. In these diagrams the immunogenic indices defined as

$$
I=\frac{N}{\sum_{n=1}^{n=N}\left(\frac{1}{t}\right)}
$$

are plotted as ord nates against the zone electrophoresis sample as abscissae. In equation (1) $N$ is the number of mice or tubes under observation and $t$ is the time in days for the occurrence of c.N.S. symptoms in mice or the full development of cytopathic effect.

In the tissue culture tests three tubes were used for each serum. $N$ varied between 
15 and 18, depending on whether a guinea-pig in a group of six died during the immunization period.

Fig. 3 shows the relationship between concentration of antigen and immunogenic index. This curve was plotted from data obtained from a guinea-pig immunization experiment in which a portion of the concentrated antigen used in the zone electrophoresis run was employed.

Although the curve obtained does not warrant extrapolation above the " -1 dilution' and therefore cannot be used for the estimation of the relative antigenicity of sample 4 (Fig. 2), it does indicate that the immunogenic response is dependent on antigen concentration, and consequently that the bulk of the antigen was concentrated in fraction (4) of the zone electrophoresis column.

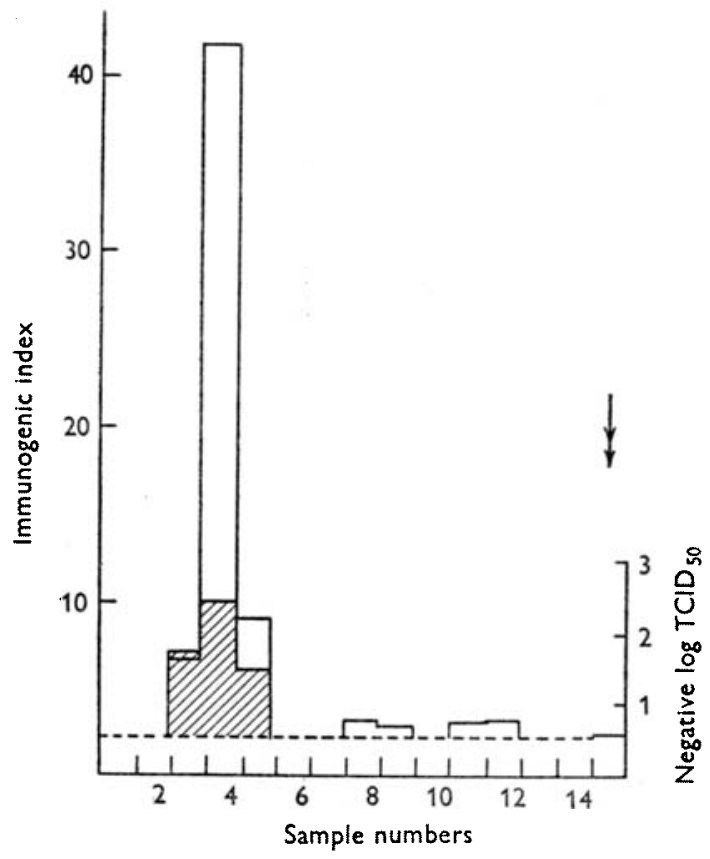

Fig. 2. Diagram showing the results of immunization of guinea-pigs with the different samples from the zone electrophoresis column. The neutralization tests were done in tissue culture tubes. Individual sera were tested against $10^{3} \mathrm{~T} \smile \mathrm{ID}_{\mathrm{y} 0} / 0.5 \mathrm{ml}$. Three tubes were used per serum virus mixture. The ordinates measure the immunogenic response of the different groups of guinea-pigs. Double arrow shows position of phenol red. The dotted line is the level in the diagram below which no antibody is present, and its position was obtained from control neutralization tests using preimmunization guinea-pig sera.

In Table 1 is given a summary of the results of zone electrophoresis experiments conducted on active and partially inactivated $\mathrm{MEF}_{1}$ virus.

In Fig. 2 is shown the distribution of virus activity in the column (shaded portion). This histogram is to be compared with the zone electrophoresis histograms Fig. $4 a$ and $4 b$, of unformalinized $\mathrm{MEF}_{1}$ virus obtained under identical conditions of $\mathrm{pH}$ buffer concentration and voltage gradient. (The two diagrams are presented in order to show that the results were reproducible.) 
From the distances traversed by the active virus peaks in Fig. 4 and of the formaldehyde-treated virus (shaded portion in Fig. 2), it is evident that the mobility of the virus particles which still retained their activity after formalinization is approximately $25 \%$ higher than untreated virus. This is an indication that the surfaces of poliovirus particles may be affected by the inactivating agent but that some particles may still retain their infectivity.

Table 1. Comparison of results obtained by zone electrophoresis on active and partially inactivated $M E F_{1}$ poliovirus. Borate buffer $p H$ 8-6. Sugar gradient $40 \%-0 \%$. Traces of phenol red and rabbit haemoglobin ( $\mathrm{Hg}$ bl.) added as reference substances to the fully active material. Only phenol red added to partially inactivated virus.*

\begin{tabular}{|c|c|c|c|c|c|}
\hline $\mathrm{MEF}_{1}$ material & $\begin{array}{l}\text { Distance } \\
\text { Hgbl. } \\
\text { migrated } \\
\text { (cm.) }\end{array}$ & $\begin{array}{l}\text { Distance } \\
\text { phenol } \\
\text { red } \\
\text { migrated } \\
\text { (cm.) }\end{array}$ & $\begin{array}{c}\text { Distance } \\
\text { infectivity } \\
\text { migrated } \\
\text { (cm.) }\end{array}$ & $\begin{array}{c}\text { Tyndall } \\
\text { light } \\
\text { scattering } \\
\text { (cm.) }\end{array}$ & $\begin{array}{c}\text { Peak of } \\
\text { antigen } \\
\text { (cm.) }\end{array}$ \\
\hline \multirow{2}{*}{$\begin{array}{l}\text { T.c. fluid concentrated } \\
\text { acentrifugation }\end{array}$} & 3 & 16 & $2-3$ & - & $\ldots$ \\
\hline & 3 & 16 & $2-3$ & - & - \\
\hline r.c. fluid partially in. & - & 15 & $3-4$ & $3 \cdot 5$ & $3-4$ \\
\hline
\end{tabular}

Infective T.c. fluid concentrated

by ultracentrifugation

Ibid.

Infective r.c. fluid partially in-

activated by $\mathrm{H}$. CHO and concen-

trated by ultracentrifugation

* Polson \& Cramer (1958) have shown that the addition of haemoglobin had no influence on the electrophoretic mobility of Type 1 poliovirus.

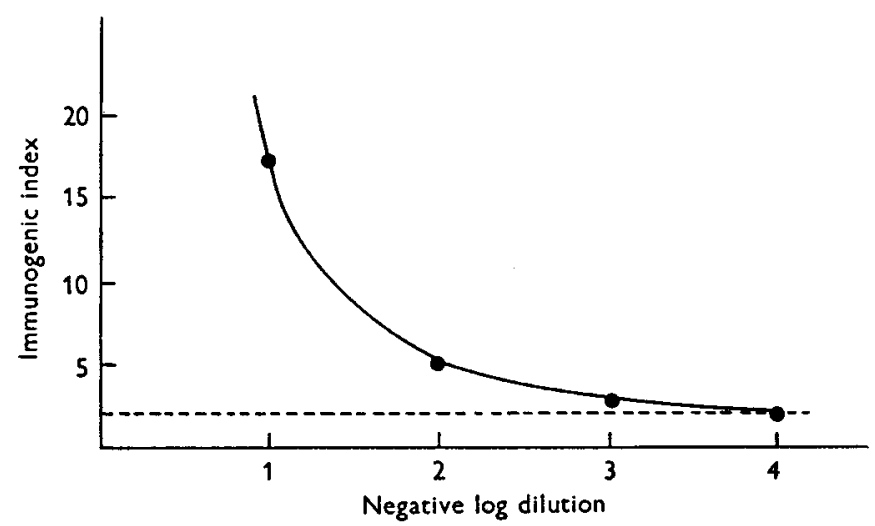

Fig. 3. Relationship between immunogenic index (response) and concentration of the antigen. Six guinea-pigs were immunized with each dilution of the virus concentrate. Test antigen $10^{3}$ TCID $_{50} / 0 \cdot 5 \mathrm{ml}$. Three tubes were used per individual serum.

Portions of the samples were freed of sugar $\mathrm{ky}$ dialysis against distilled water for $16 \mathrm{hr}$. followed by pervaporation to approximately 1 c.c. and dialysis against saline. They were all adjusted to the same volume with saline and tested against homologous immune sera by double gel diffusion using the technique of Polson $(1958 a)$. The reactions were performed in the precision glass precipitin apparatus as supplied by L. K. B. Produkter (Stockholm). In Pl. 2 are shown the tubes in which precipitin bands were noticed. Sample 3 showed a single band, samples 4 and 5 
showed two precipitin bands spaced approximately 1.5 and $2.5 \mathrm{~mm}$. apart respectively. The bands in 3 and 5 are closer to the antigen meniscus than those formed by the material in sample 4, which is an indication that these samples contain considerably less antigen than sample 4, Polson (1958b).

The fact that sample 3 showed a single band and 4 and 5 double bands is an indication that a certain degree of separation had taken place between the two components during zone electrophoresis. The lesser of the two antigen components appeared to have the higher mobility.

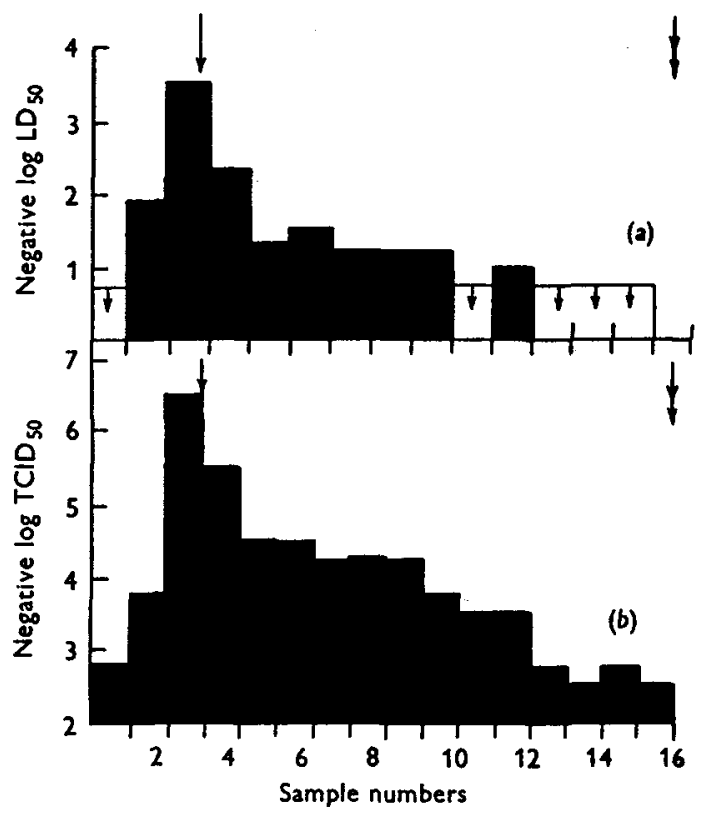

Fig. $4 a$ and $4 b$. Zone electrophoresis diagrams of $\mathrm{MEF}_{1}$ virus concentrated from T.C. fluid. The single and the double arrows indicate the position of the rabbit haemoglobin and the phenol red bands respectively.

In two zone electrophoresis experiments on 4000-fold concentrates of fully inactivated $\mathrm{MEF}_{1}$ poliovirus, the opalescent bands and the peak of the antigenicities (as determined by double gel diffusion) were located in the same relative positions to the phenol red band and the initial positions as in the experiment with the partially inactivated virus. The second precipitin band, however, was absent in these tests. It must be stated here that Collans (Type 2) hyperimmune serum was used in these precipitin tests on account of the unavailability of the homologous immune serum at the time when the test was performed. More work along these lines is essential before any conclusion can be drawn regarding the specific nature of the minor precipitin band.

\section{SUMMARY}

It was shown in this work that the electrophoretic mobility of the $\mathrm{MEF}_{1}$ strain of poliovirus was increased approximately $25 \%$ after interrupted inactivation with formaldehyde. This is in accordance with past observations on the behaviour of 


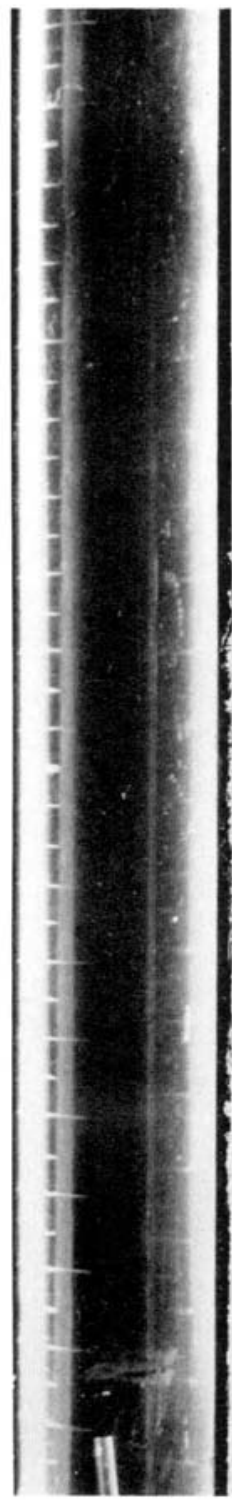

5

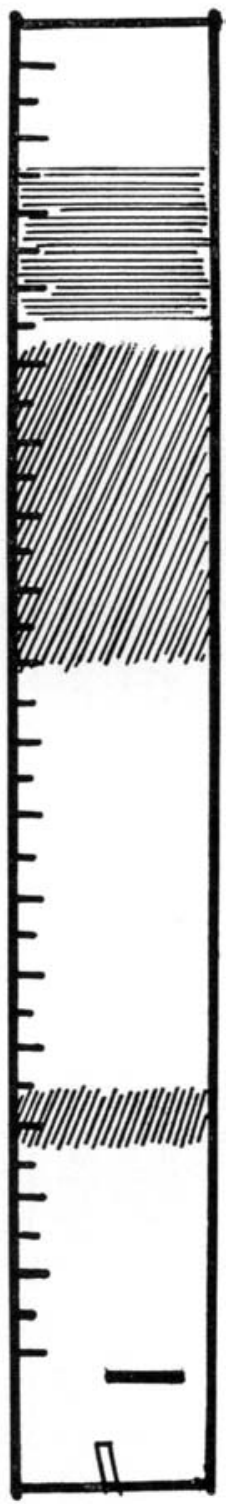

A. POLSON, J. W. F. HAMPTON AND D. DEEKS 

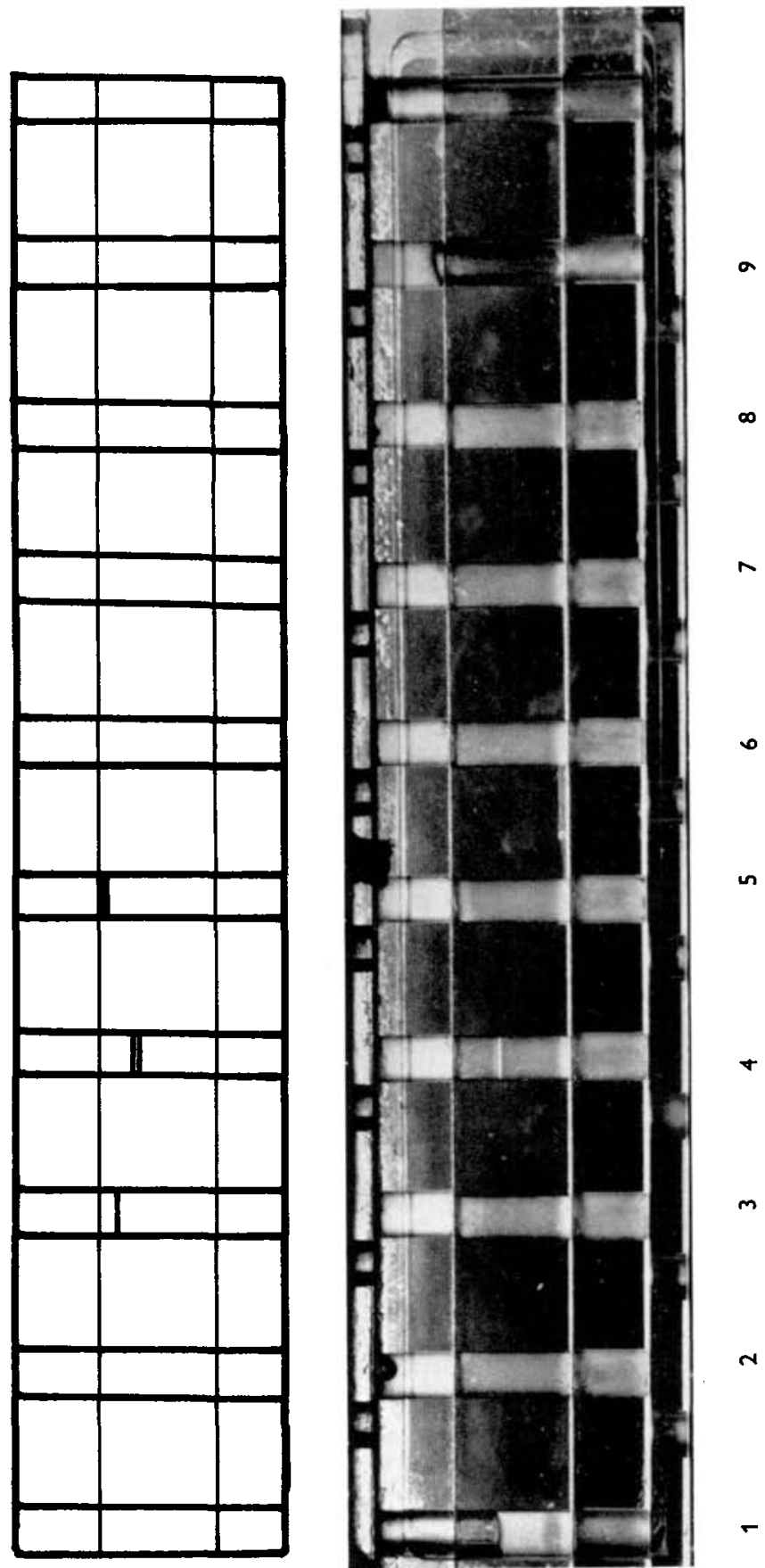

A. POLSON, J. W. F. HAMPTON AND D. DEEKS 
formaldehyde-treated proteins. The residual live virus had the same mobility as the 'killed' virus, thus indicating that the surfaces of all the virus particles have been affected to the same degree by the inactivating agent.

Gel precipitin tests performed on the different samples obtained by zone electrophoresis showed, in addition to the main antigen, the presence of a small amount of a second component of slightly higher mobility, and, as it occurs in the main fraction and the sample thereafter it probably has a slightly higher mobility than the main component.

The antigenic properties of the different fractions as shown by the production of antibodies in guinea-pigs correspond with the presence of precipitating antigen in the samples in the region of highest antigen concentration. The faint antigenicities of the fractions obtained from the regions higher up in the zone electrophoresis column are due to small amounts of virus antigen similar to that found in the column on electrophoresis of untreated $\mathrm{MEF}_{1}$ virus, bearing in mind that the inactivated virus was concentrated approximately 2000 times for zone electrophoresis.

The authors are grateful to Professor A. Kipps for his continued interest in this work and to the staff of the Polio Research Foundation, Johannesburg for the generous supply of $5 \mathrm{l}$. of $\mathrm{MEF}_{1}$ infected tissue culture fluid.

\section{REFERENCES}

Circle, S. J. \& SMith, A. K. (1941). J. Phys. Chem. 45, 916.

Gard, S., Wesslen, T., Fragreus, A., Svedmyr, A. \& Olin, G. (1956). Arch. ges. Virisforsch. 6, 401.

HaAs, R., Thomssen, R., Dostal, V. \& Ruschmann, E. (1959). Arch. ges. Virusforsch. 9, 470.

Polson, A. (1958a). Science Tools, 5, 17.

Polson, A. (1958b). Biochim. Biophys. Acta, 29, 426.

Polson, A. \& Cramer, R. (1958). Biochim. Biophys. Acta, 29, 187.

Polson, A. \& Hampton, J. W. F. (1957). J. Hyg., Camb., 55, 344.

Svensson, H. \& VALMET, E. (1955). Science Tools, $2,11$.

\section{EXPLANATION OF PLATES}

\section{Plate 1}

Photograph of the zone electrophoresis gradient column showing (1) the tip of the capillary; (2) the initial position of the material; (3) the layer showing strong Tyndall light scattering; (4) a broad zone showing very faint light scattering (barely visible in the photograph, but its position and extent indicated by diagonal stripes in the accompanying diagram); and (5) the position of the reference phenol red band (hardly visible in the photograph, but its position indicated on the diagram by horizontal stripes). The distances through which 3 and 5 migrated were 3.5 and $15 \mathrm{~cm}$. respectively.

\section{Plate 2}

Gel precipitin tests on the first nine samples from the zone electrophoresis column, after electrophoresis of the formaldehyde-treated virus. The maximum antigen concentration is shown by sample 4 which shows a double band. A faint single band and a faint double band were shown by samples 3 and 5 , respectively. These are barely visible in the photograph, but the positions of all the bands are indicated in the diagram above. The serum is held in the bottom cavities of the apparatus. 